\title{
Influence of climatic conditions on the occurrence of wheel track deformation on asphalt paved roads
}

\author{
Iroda Saidakberova, Sirojiddin Yadgarov ${ }^{1 *}$, Bobomurod Qurbonov, and Zulfiya Pulatova \\ Tashkent State Transport University, Tashkent, Uzbekistan
}

\begin{abstract}
When the car moves, a vertical, longitudinal and transverse dynamic force is generated, where there is a link between the road cover and the wheel. Repeated loads from vehicles and the impact of climatic factors lead to deformation in the pavement and pavement of the road. In deformation and deformation, the geometric dimensions and durability of the road pavement are lost. Disturbances-loss of dimensions and loss of durability of parts of the construction is understood. In practice, all types of deformation and distortion are often regarded as a drawback of road conditions [1].
\end{abstract}

\section{Introduction}

Deformation of the wheelbarrow on highways is a specific type of road construction (road pavement, road beam); on the road's surface, honeycombs are formed along the length. Even if the wheel track deformation occurs in the upper layer of the road pavement, it also affects the road junction and Road beam layers.

Deformation of the wheel track-asphalt concrete can be formed in all types of pavement pavements, but the change in their formation and depth will be different [2].

Despite the strength of the road beam and asphalt coating layers materials, the formation of the deformation of the wheel track is absorbed in the upper layer of asphalt coating under the influence of the wheel of vehicles. In real conditions, a wheel track is formed as a result of these processes. Like many other deformations, the formation of the wheel track deformation is caused by two negative factors:

- External factors-the effect of the load, climatic factors, especially air turbidity and sun rays, as well as the wetting of the grunt layer;

Internal factors-the physico-mechanical properties of road construction, the strength of silica, structural condition, the strength and density of road pavements:

\section{Method and Materials}

According to the longitudinal profile shape of the highway motion belt, The Shape of the deformation of the wheel trail can be seen on the roads; the wheel trail on the paved

\footnotetext{
${ }^{1 *}$ Corresponding author: sirojtdtutf@gmail.com
} 
pavement highways can be formed from two and more. The total depth of deformation of the wheel track is 2 . It can be $150 \mathrm{~mm}$ and more. Norms of deformation of the wheel track on asphalt concrete pavement highways in the Republic of Uzbekistan are presented in the documents (Table 1) [3].

Table 1.

\begin{tabular}{|c|c|c|}
\hline \multirow{2}{*}{$\begin{array}{c}\text { Approximate speed of movement, } \\
\mathrm{km} / \mathrm{h}\end{array}$} & \multicolumn{2}{|c|}{ Wheel track depth, } \\
\cline { 2 - 3 } & Fixed & $\begin{array}{c}\text { Limit } \\
\text { allowed }\end{array}$ \\
\hline$>120$ & 4 & 20 \\
\hline 120 & 7 & 20 \\
\hline 100 & 12 & 20 \\
\hline 80 & 25 & 30 \\
\hline 60 and over & 30 & 35 \\
\hline
\end{tabular}

Development of recommendations to prevent the occurrence of wheel track deformation in hot climatic conditions on asphalt pavement roads widely spread in the Republic of Uzbekistan. highways;

- to examine the appearance of wheel track deformation on asphalt concrete pavement

- measurement of temperature in asphalt concrete coatings and analysis of results;

- to examine the impact of vehicles and air-climate factors on the deformation of the wheel track formed in asphalt concrete pavement;

Development of recommendations against the occurrence of wheel track deformation on highways with asphalt concrete coating.

In the Republic of Uzbekistan, a traditional measuring instrument (3-meter roulette) is used to measure wheel track deformation. Still, now several different instruments are used in the measurement of wheel track in developed foreign countries:

- KP-514 MP (Russia);

- Laser RST (USA va Sweden);

- SCRIM (England);

- ANDERA, Grip Tester, SIRONA (France);

- ARAN (Canada, the Netherlands, Czech);

- WUD (Czech);

- $\quad$ SRT - 3 (Skid Resistance Tester) (Poland)

- OSCAR (Norway) [7].

The norms and procedure for measuring and evaluating the wheel track on the road pavement (3-meter rail) are given in the normative document IQN 05 - 2011.

\section{Results and Discussion}

As can be seen from the measurement work done above, when the air temperature is high, that is, the temperature will be higher than the 50s (according to the normative documents, $50{ }^{\circ} \mathrm{C}$ will be projected when designing). We need to limit the entry of heavy trucks when the air temperature is high, but these measures are not an exhaustive solution to the problem. The air temperature has a direct effect on the appearance of a wheel trail (figure 1). 


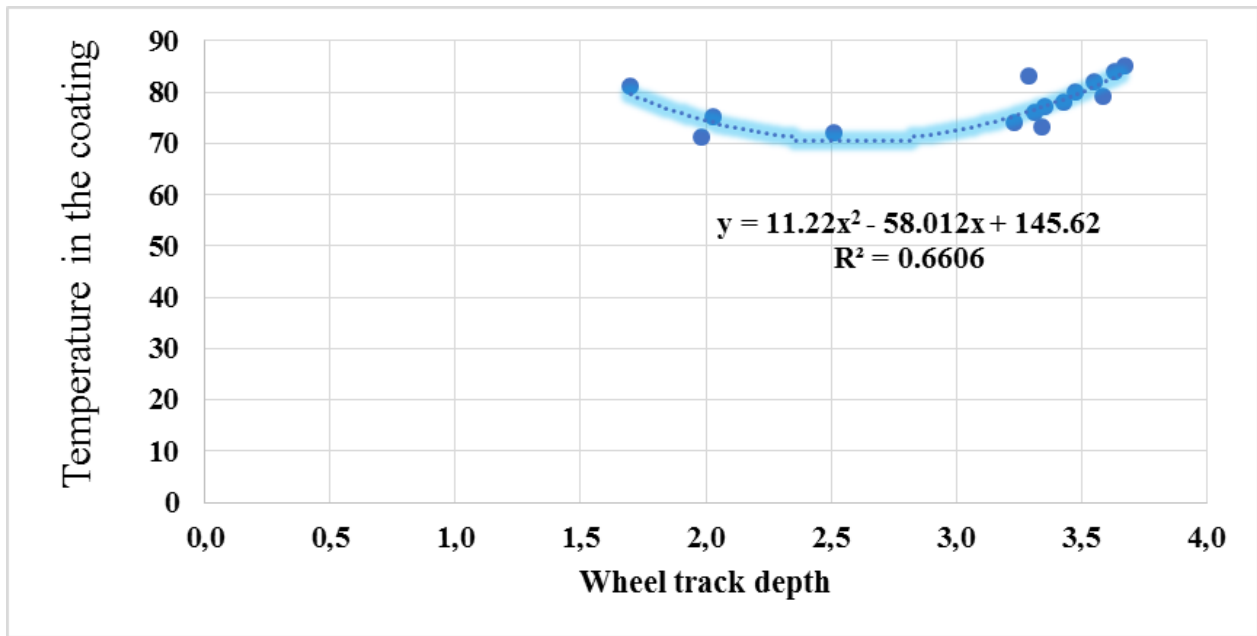

Fig 1. The dependence of air temperature on the wheel track

In 2007-2008, the old normative documents on the calculation of road junctions were adopted for re processed and design of highways, cargo calculated on 100-130 kn axis [4]. According to re processed SSR 2.05.02-2007 "highways", in the design of road junctions, we select loads corresponding to normal loads on the axis of the two-axle cars calculated. If the calculated load in the project task is not specified separately, for the calculated load, we take the load corresponding to the project machine of Group A (Table 2) [5-7].

Table 2.

\begin{tabular}{|c|c|c|c|c|}
\hline \multirow{2}{*}{$\begin{array}{l}\text { Calculation group } \\
\text { of downloads }\end{array}$} & \multirow{2}{*}{$\begin{array}{l}\text { Normal static load } \\
\text { on the axle, kn }\end{array}$} & \multirow{2}{*}{$\begin{array}{l}\text { Normal static load, kn, falling } \\
\text { from the wheel of the selected } \\
\text { vehicle to the coating surface }\end{array}$} & \multicolumn{2}{|c|}{$\begin{array}{c}\text { Accounting } \\
\text { parameters of loading }\end{array}$} \\
\hline & & & $P, \mathrm{MPa}$ & $D, \mathrm{sm}$ \\
\hline $\mathrm{A}^{1}$ & 100 & 50 & 0.60 & $37 / 33$ \\
\hline $\mathrm{A}^{2}$ & 130 & 65 & 0.60 & $42 / 37$ \\
\hline
\end{tabular}

Note: in the photo - for the moving wheel, in the denominator-for the moving wheel.

Based on Table (Table 2), it is possible to determine the value of the coefficient that leads to the calculated car and the approximate speed of movement.

To understand the measurement processes (figure 2), dynamic voltages obtained from the optical device (a) and then (b) can be seen below. Analysis of the obtained regression equations showed that asphalt concrete was determined to accelerate the formation of Wheel Trail deformation due to the effect of the temperature on the pavement and the forces of tension falling from the vehicles. 


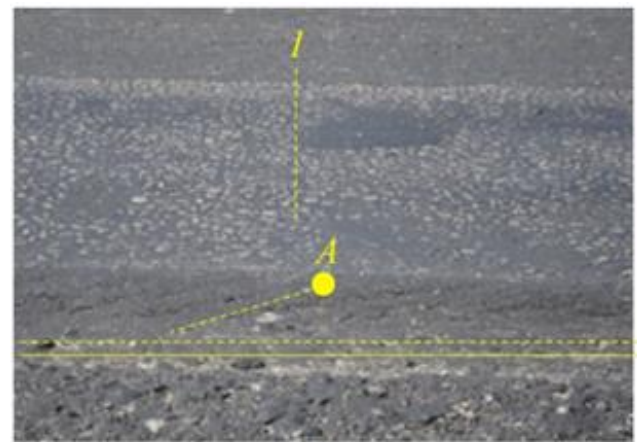

a

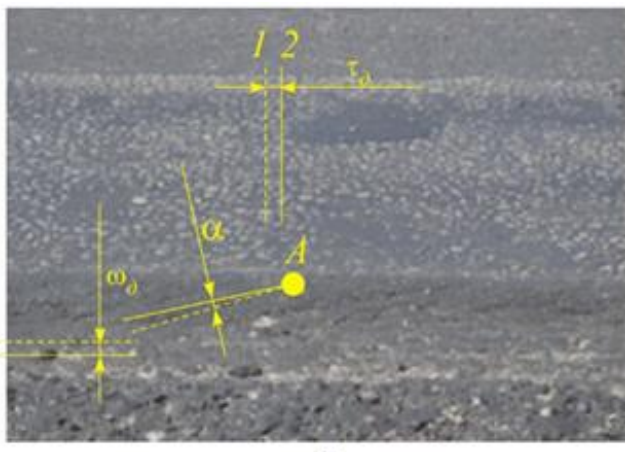

$b$

Fig. 2. graphic representation of measurements. a) before exposure of vehicles; b) after exposure.

The quantitative assessment of this phenomenon requires forecasting the process of changing the coating temperature, taking into account the variety of climatic conditions of objects in different regions. Changing the temperature in the road pavement construction occurs under the influence of external air, such as air temperature, the intensity of solar radiation, wind speed and direction.

\section{Conclusions}

Recommendations against the appearance of wheel track deformation on highways with asphalt concrete coating is adding "Unirem" modifier to the composition of asphalt concrete mixtures.

To prevent the appearance of deformation of the wheel track on the roads with asphalt concrete coating, it is possible to recommend the modifier "Unirem", which is produced by the firm "Unikom". The main component of this modifier is the active rubber powder, which is obtained from the tires of vehicles that are excluded from the use of highperformance. It has long been using outdated automobile tires as a bitumen modifier in some developed states. Some US companies have been producing polymer powders that are used for road coatings from rubber waste in the 60 years [8].

The use of the unirem modifier solves deformation dressing of the wheelbarrow in extremely high-temperature conditions on highways, including summer periods. When analyzing the results of the application of Unirem in the Russian Federation, it was observed that the deformation of the wheel track decreased by an average of $50 \%$.

When the" Unirem " modifier is used in a mixture of asphalt concrete:

- Significantly increases resistance to abrasion;

- Significantly reduce the deformation that occurs due to temperature;

- Prevents deformation of the wheel track;

- Prevents flow and coating silks;

- High water resistance;

- The technology of producing a mixture of asphalt concrete does not make changes, and the technology of placing asphalt concrete on the object;

- Improves traffic handling indicators on paved concrete pavement roads;

- Reduces the service life of the coating and the cost of repairs;

- The possibility of application in different climatic zones;

- Eliminate environmental problems.

"Univer" composite materials must comply with the requirements and standards specified in table 3 [8]. 
The polymer additive "Unirem" was brought to the optimal appearance to add to the composition of asphalt concrete mixtures. The modifier Univer is produced in two forms: in the form of powder (unirem-001) and granular (unirem-002) (figure 3) [9].

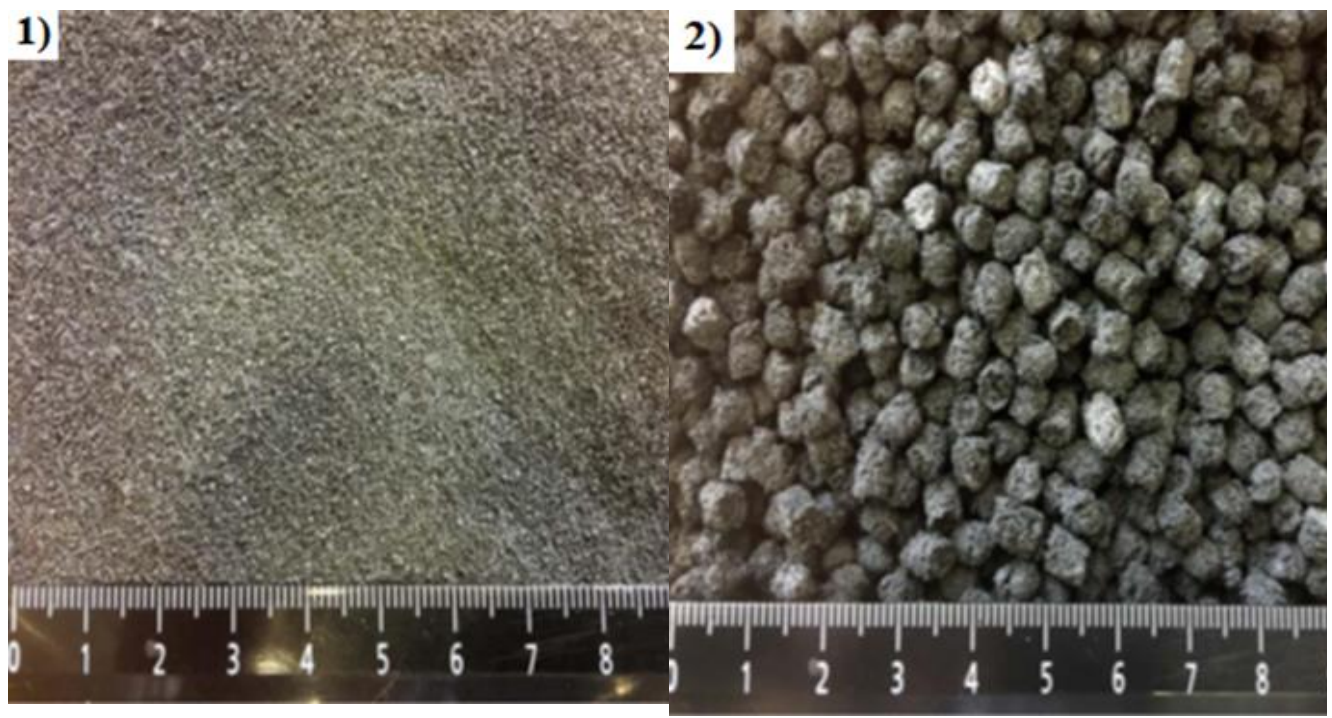

Fig. 3. Views of the modifier Univer: 1) powder form; 2) granulometric form.

When using the" Unirem " modifier, laying and condensation of a mixture of asphalt concrete is carried out following the requirements of SSR 3.06.03. The results of laboratory testing of a type of asphalt concrete mixture were found to improve the physico-mechanical properties of the "Unirem" additive (Table 3) [9].

Table 3. Physical and mechanical properties of the additive "Unirem"

\begin{tabular}{|c|c|c|c|c|}
\hline \multirow{2}{*}{ Pointers } & \multicolumn{2}{|c|}{ The amount of "Unirem", \% } & \multirow{2}{*}{ GOST 9128 requirements } \\
\cline { 2 - 4 } & 0 & 0.8 & 1.0 & \multirow{2}{*}{ It should not be less than 2.2} \\
\hline Silica durability R, MPa $20^{\circ} \mathrm{C} ;$ & 3.25 & 3.5 & 4.4 & \multirow{2}{*}{${ }^{\circ} \mathrm{C}$} \\
\hline $0{ }^{\circ} \mathrm{C}$ & 1.25 & 1.37 & 1.4 & It should not be less than 0,9 \\
\hline $\begin{array}{c}\text { Water resistance, no less } \\
\text { Water resistance, long saturated to } \\
\text { water, should not be } \\
\text { underestimated }\end{array}$ & 0.17 & 6.8 & 7.81 & It should not be less than 1.2 \\
\hline Internal friction coefficient & 0.83 & 0.91 & 0.95 & It should not be less than 0.75 \\
\hline Hook up in shift, $50^{\circ} \mathrm{C}, \mathrm{MPa}$ & 0.59 & 0.87 & 0.9 & It should not be less than 0.87 \\
\hline $\begin{array}{c}\text { Resistance to cracking in stretch } \\
\text { marks }\end{array}$ & 0.51 & 0.40 & 0.47 & It should not be less than 0.85 \\
\hline Water Viscosity W, \% & 2.6 & 2.2 & 2.0 & $3.5-6.0$ \\
\hline Average density, g/cm & & 0.96 & It should not be less than 0.25 \\
\hline
\end{tabular}


Under the influence of external factors, changes in strength and deformation properties occur in asphalt concrete coatings. Based on the analysis of Physico-mechanical indicators of asphalt concrete mixtures, it can then be concluded that the composition of asphalt concrete increased when additives were added. Experimental studies have shown that the additive-free mixture was equal to $20 \mathrm{MPa}$ at a temperature of $3.25{ }^{\circ} \mathrm{C}$ and after the addition was equal to $0.8 \mathrm{MPa}$ at $3.5 \%$, and $1.0 \mathrm{MPa}$ at $4.4 \%$. These indicators are significantly higher than the requirements of GOST 9128 (at least $2.2 \mathrm{MPa}$ ). The same condition was observed at $50^{\circ} \mathrm{C}(1.25 \mathrm{MPa}$ without additives and $1.37 \mathrm{MPa}$ and $1.4 \mathrm{MPa}$ with polymer modifiers applied, with a minimum requirement of GOST 9128 to $0.9 \mathrm{MPa}$ ).

We can see the economic effect of" Unirem " at the bottom of the repair intervals. If the repair period on the roads with the usual asphalt concrete coating is an average of 5 years, then when the modifier is added, We can see an increase in the repair period by an average of 7 years [8-13].

The above-recommended modifier "Unirem" can be used in a mixture of CHMA with ham. To determine the physico-mechanical properties of the CHMA, tests were conducted for compliance with the requirements of GOST 31015-2002, and the results obtained (Table 4) are presented.

Table 4. Physical and mechanical properties of the PMA compliance test results

\begin{tabular}{|c|c|c|c|c|c|}
\hline \multirow[b]{2}{*}{ Pointers } & \multirow[b]{2}{*}{$\begin{array}{l}\text { Requirements for } \\
\text { GOST 31015- } \\
2002\end{array}$} & \multicolumn{4}{|c|}{ Real indicators } \\
\hline & & 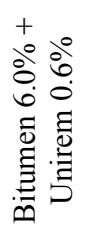 & 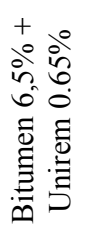 & 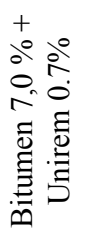 & 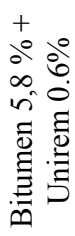 \\
\hline $\begin{array}{l}\text { Average density, } \\
\mathrm{g} / \mathrm{sm} 3\end{array}$ & Not required & 2.54 & 2.54 & 2.55 & 2.38 \\
\hline Mineral part, \% & $15-19$ & 17.5 & 17.9 & 18 & \\
\hline Viscosity, \% & $1.0-4.0$ & 2.57 & 1.75 & 1.18 & \\
\hline $\begin{array}{c}\text { Silisha strong R, } \\
\text { MPa: }\end{array}$ & $\begin{array}{l}\text { It should not be } \\
\text { less than } 2.2\end{array}$ & 2.65 & 2.40 & 2.05 & \\
\hline $\begin{array}{l}20 \text { Harald; } \\
50 \text { cents. }\end{array}$ & $\begin{array}{l}\text { It should not be } \\
\text { less than } 0.65\end{array}$ & 1.08 & 0.94 & 0.73 & \\
\hline $\begin{array}{c}\text { Water resistance } \\
\text { with long saturation } \\
\text { to water }\end{array}$ & $\begin{array}{l}\text { It should not be } \\
\text { less than } 0.85\end{array}$ & 0.80 & 0.86 & 0.89 & \\
\hline $\begin{array}{l}\text { Internal friction } \\
\text { coefficient }\end{array}$ & $\begin{array}{l}\text { It should not be } \\
\text { less than } 0.93\end{array}$ & 0.95 & 0.95 & 0.95 & \\
\hline $\begin{array}{l}\text { Stripping in the } \\
\text { Silk, } \\
50 \mathrm{~s} \text { away, MPa }\end{array}$ & $\begin{array}{l}\text { It should not be } \\
\text { less than } 0.18\end{array}$ & 0.26 & 0.22 & 0.17 & \\
\hline
\end{tabular}

The use of the modifier" Unirem " has a significant impact on the development of wheel track deformation on highways; also, it has an anti-impact effect on the appearance of a wheel track even under high-temperature conditions.

When the modifier " Unirem "is added to the composition of the CHMA, the cost of the asphalt concrete mixture may slightly increase; that is, the cost of 100 tons of the CHMA is 45.211 .998 sum, the cost of 100 tons of the modifier" Unirem " is 48.495 .953 sum, the difference between them is 3.283 .955 sum. It was concluded that the period of repair exceeds 5 years to 7 years. 


\section{Reference}

1. Vasiliev A. P. Operation of highways 2, Publishing Center, "Academy", (2010)

2. IQN 05-2011 "Rules for transportation and assessment of the condition of highways", Tashkent (2011).

3. Leonovich I. I., Bogdanovich S.V., Diagnostics of highways, BNTU, Minsk (2012).

4. Makhmudov Y. N. Research of strength and deformation stability of asphalt concrete coatings, Moscow (1973)

5. Apelin V.K., Schuck, A.M., Yakovlev Y.M. Test and evaluation of durability of nonrigid road clothes, Moscow, "Transport" (1989).

6. Gorelyshev N. V. Asphalt concrete and other bituminous materials, p. 157, Moscow Mozhaisk-Terra (1995)

7. Evgeniev I. E., Tulaev A.Y., Porozhnyakov V.S. Operational quality control of the roadbed and road clothes, Moscow "Transport" (1985)

8. Georgievna Z.U. "Rubber-bitumen composites based on road bitumen and active rubber powder (APDDR): preparation, structure, rheological properties, application", Moscow (2016)

9. Presentation "New generation road surfaces"."New construction technologies" Moscow (2015)

10. Tukashev Zh. B., Adilkhanova L. A. Issledovaniye napryazhenno-deformirovannogo sostoyaniya dorozhnogo pokrytiya, Geologiya, geografiya i global'naya energiya, №. 2, p. 37, (2010)

11. Mikheyeva, T.I., Bugakov, A.I., and Chugunov, A.I. Avtomatizirovannaya sistema monitoringa sostoyaniya dorozhnogo pokrytiya, In Perspektivnyye informatsionnyye tekhnologii, pp. 845-847, (2018).

12. Vysotskaya M. A. Obzor sostoyaniya segmenta propitochnykh materialov dlya pokrytiy avtomobil'nykh dorog, Vestnik Belgorodskogo gosudarstvennogo tekhnologicheskogo universiteta im. V.G. Shukhova, № 8, (2018)

13. Gorshkov A. S. i dr. Fiziko-mekhanicheskiye svoystva naledi, razrushayemoy reztsom pri ochistke pribordyurnoy zony dorozhnogo pokrytiya, Sovremennyye problemy nauki i obrazovaniya, №. 4, pp. 201-201, (2014) 